\title{
Literature Survey of Interleaved DC-DC Step- Down Converters for Proton Exchange Membrane Electrolyzer Applications
}

\author{
Vittorio Guida, Damien Guilbert, and Bruno Douine
}

\begin{abstract}
Recently, the use of electrolyzers for hydrogen production through water electrolysis is of great interest in the industrial field to replace current hydrogen production pathways based on fossil fuels (e.g. oil, coal). In order to reduce the emission of pollutants into the atmosphere and minimize the cost of electricity, it is preferable to use renewable energy sources (e.g. solar, wind, hydraulic). The electrolyzers must be supplied with a very low DC voltage in order to produce hydrogen from the deionized water. For this reason, DC-DC step-down converters are generally used. However, these topologies present several drawbacks from output current ripple and voltage gain point of view. In order to meet these expectations, interleaved DC-DC stepdown converters are considered as promising and interesting candidates to supply proton exchange membrane (PEM) electrolyzers. Indeed, these converters offer some advantages including output current ripple reduction and reliability in case of power switch failures. In addition, over the last decade, many improvements have been brought to these topologies with the aim to enhance their conversion gain. Hence, the main goal of this paper is to carry out a thorough state-of-the-art of different interleaved step-down DC-DC topologies featuring a high voltage gain, needed for PEM electrolyzer applications. Furthermore, a comparison of candidate interleaved step-down converters not only from the voltage ratio point of view but also from the phase and/or output current ripple point of view.
\end{abstract}

Index Terms - electrolyzer, interleaved converters, renewable sources, conversion ratio, current ripple, energy efficiency, power switch faults, reliability.

\section{INTRODUCTION}

$\mathrm{T}$ HE random behavior of the renewable energy sources (RES) makes the hydrogen production and storage an engaging and efficient solution. This is because hydrogen has much higher specific energy than the classical storage devices such as batteries [1]. On planet Earth, there are several resources available for hydrogen production such as fossil fuels (e.g. natural gas and coal), and RES (e.g. biomass and water). However, from an environmental point of view, hydrogen production from fossil fuels (although it does save money) contributes considerably to the release of greenhouse gases and other pollutants into the atmosphere [2]. In this perspective,

V. Guida, D. Guilbert, B. Douine are with the Group of Research in Electrical Engineering of Nancy (GREEN), Université de Lorraine, 54500, Vandoeuvre-lès-Nancy, FRANCE (e-mail: vittorio.guida@univ-lorraine.fr , damien.guilbert@univ-lorraine.fr , bruno.douine@univ-lorraine.fr ). water is considered an attractive raw material for hydrogen production (having two atoms of hydrogen and one of oxygen, as is well known). Being free of nitrogenous, carbonaceous or sulfured species, water is ideal for hydrogen production, contributing to the reduction of polluting emissions. Among the different hydrogen production processes, starting from water, the most consolidated is electrolysis. Water electrolysis allows obtaining practically pure hydrogen. This process, for which electricity currently has a cost up to three or four times higher than the methane used for steam reforming, becomes economically acceptable as a result of technological innovations and under extremely low-cost conditions of electricity (if electricity is produced from RES) [3]. Water electrolysis is based on an electrochemical reaction using electricity to split water into hydrogen and oxygen; it is carried out by means of an electrolyzer (EL). There are three types of ELs in the literature: proton exchange membrane (PEM) EL, alkaline EL, and solid oxide EL (the latter exists only in the field of research and development) [4].

In order to produce hydrogen from deionized water, the EL must be supplied with a very low DC voltage. Hence, the use of DC-DC converters is decisive to adjust the voltage levels between the EL and the DC bus. Generally, classic DC-DC step-down converters are used for this purpose due to their simplicity and low cost $[5,6]$. Unfortunately, these converters have several drawbacks from availability in case of electrical failures, output current ripple, conversion ratio, and energy efficiency point of view for EL applications. The same issues have been highlighted regarding classic step-up converters for fuel cell applications $[7,8]$.

Over the last decade, a family of DC-DC step-down converters called interleaved has spread particularly in the research field. Indeed, many interleaved step-down topologies have been proposed in the scientific literature [9-16], bringing improvements (e.g. energy efficiency optimization, output current ripple minimization, and availability in case of electrical failures) compared to the conventional interleaved step-down converter. As it has been mentioned earlier, ELs must be supplied with a very low DC voltage; so interleaved DC-DC step-down converters are suitable for this type of applications. 
Starting from these observations, the main purpose of this work is to carry out a thorough literature survey focused on the family of interleaved DC-DC step-down converters featuring a high voltage gain.

This article is divided into six sections. After this Introduction providing the current state-of-the-art and issues, Section II compares the three existing technologies of ELs with the aim to select the most suitable technology for this study. Then, Section III presents the main requirements of DC-DC converters for EL applications. Afterward, in Section IV, candidate interleaved step-down topologies for EL applications are presented including their advantages and drawbacks. After that, in Section V, a comparison is carried out between candidate interleaved converters, especially from voltage gain and phase and/or output current ripple point of view. Finally, in Section VI, conclusions and perspective of the work are given.

\section{PROTON EXCHANGE MEMBRANE TECHNOLOGY}

Currently, different types of EL can be distinguished by their electrolyte and the charge carrier: (1) alkaline EL; (2) proton exchange membrane (PEM) EL; and (3) solid oxide (SO) EL $[2,3]$. Table I provides the main features of each technology; while Table II introduces the advantages and drawbacks of each technology. From Tables I and II, alkaline and PEM ELs are currently the two main technologies, which are commercially available. Alkaline ELs are the most mature and widespread compared to PEM ELs (still under development). As highlighted in Tables I and II, alkaline ELs have a higher durability and gas purities, and cheaper catalysts than PEM ELs. However, PEM ELs have several advantages over alkaline ELs, such as compactness, fast system response, wide partial load range and high flexibility in terms of operation. As a result, this technology is an attractive option for integration into the grid including renewable power generating systems [3]. For this reason, PEM ELs are considered within hybrid renewable energy systems and hydrogen production pathways based on renewable energy sources.

\section{MAIN REQUIREMENT FOR DC/DC CONVERTERS}

Like for fuel cells, DC/DC converters are needed to interface the DC voltage grid and the EL. These converters can be used both for hybrid renewable energy systems (Fig. 1) and hydrogen production pathways based on renewable energy sources (Fig. 2). Generally, a PEM EL needs a very low DC voltage in order to produce hydrogen. Indeed, at rated power, the cell voltage range of a PEM EL is included between 1.75 and $2.2 \mathrm{~V}$ [2]. A higher input EL voltage can be obtained by stacking more cells. However, the number of the cells has to be limited in order to guarantee a high reliability of the PEM EL. Currently, this compromise between the EL reliability and its stack voltage (which is the sum of each cell voltage) is a challenging issue for EL applications [4]. Generally, step-down DC/DC converters are used to supply PEM ELs; whereas for fuel cell applications, step-up converters are preferred.

In any systems including a hydrogen buffer storage, DC/DC converter must meet a certain number of requirements,
TABLE I

MAIN FEATURES OF EACH ELECTROLYZER TECHNOLOGY

\begin{tabular}{|c|c|c|c|}
\cline { 2 - 4 } \multicolumn{1}{c|}{} & Alkaline & PEM & SO \\
\hline Maturity & Commercial & $\begin{array}{c}\text { Commercial } \\
\text { medium and } \\
\text { small-scale } \\
\text { applications }\end{array}$ & $\begin{array}{c}\text { Research and } \\
\text { Development }\end{array}$ \\
\hline $\begin{array}{c}\text { Current } \\
\text { density }\end{array}$ & $0.2-0.4 \mathrm{~A} \cdot \mathrm{cm}^{-2}$ & $0.6-2 \mathrm{~A} \cdot \mathrm{cm}^{-2}$ & $\begin{array}{c}0.3-0.6 \\
\mathrm{~A} \cdot \mathrm{cm}^{-2}\end{array}$ \\
\hline Cell area & $<4 \mathrm{~m}^{2}$ & $<0.3 \mathrm{~m}^{2}$ & $/$ \\
\hline Cell voltage & $1.8-2.40 \mathrm{~V}$ & $1.75-2.20 \mathrm{~V}$ & $/$ \\
\hline $\begin{array}{c}\text { Hydrogen } \\
\text { output } \\
\text { pressure }\end{array}$ & $0.05-30 \mathrm{bar}$ & $10-30 \mathrm{bar}$ & 50 bar \\
\hline $\begin{array}{c}\text { Operating } \\
\text { temperature }\end{array}$ & $60-80{ }^{\circ} \mathrm{C}$ & $50-80{ }^{\circ} \mathrm{C}$ & $700-800{ }^{\circ} \mathrm{C}$ \\
\hline $\begin{array}{c}\text { System } \\
\text { efficiency }\end{array}$ & $52-69 \%$ & $57-69 \%$ & $\begin{array}{c}>90 \% \text { (heat } \\
\text { and } \\
\text { hydrogen) } \\
<80 \% \text { (only } \\
\text { for }\end{array}$ \\
\hline $\begin{array}{c}\text { Indicative } \\
\text { system cost }\end{array}$ & $1-1.2 € / \mathrm{W}$ & $1.9-2.3 € / \mathrm{W}$ & $1.2 € / \mathrm{W}$ \\
\hline $\begin{array}{c}\text { System size } \\
\text { range }\end{array}$ & $\begin{array}{c}0.25-760 \\
\mathrm{Nm} \mathrm{m}^{3} \cdot \mathrm{h}^{-1}\end{array}$ & $\begin{array}{c}0.01-240 \\
\mathrm{Nm}{ }^{3} \cdot \mathrm{h}^{-1}\end{array}$ & $\begin{array}{c}\text { Laboratory } \\
\text { scale }\end{array}$ \\
\hline $\begin{array}{c}\text { Lifetime } \\
\text { stack }\end{array}$ & $<90000 \mathrm{~h}$ & $<60000 \mathrm{~h}$ & $\approx 1000 \mathrm{~h}$ \\
\hline
\end{tabular}

provided below [4]:

1) High energy efficiency.

2) Low electromagnetic disturbances.

3) Reduced cost.

4) High voltage ratio.

5) Low output current ripple (to optimize EL performances).

6) Ability to operate in case of electrical failures.

Among these requirements, the most important feature expected from the $\mathrm{DC} / \mathrm{DC}$ converter is a high conversion ratio. Indeed, for electrical systems including wind turbines, the DC bus voltage is very high (i.e. between a hundred and a thousand volts) [4]. Besides, current hybrid renewable energy systems with hydrogen storage based on a DC bus configuration are limited to low-power applications due to the use of classic DC/DC converters (buck for PEM EL) [17]. Hence, in order to move towards medium and high-power applications, DC/DC converters must feature high conversion ratio ability [18].

Interleaved step-down DC-DC converter topologies have much to offer for PEM ELs. Some improvements have been reported in the literature to enhance the conversion ratio ability while benefiting low output current ripple, high energy efficiency, and availability in case of electrical failures. Over the last years, many interleaved DC-DC buck converters proposed in the literature [9-16] can be suitable for PEM EL applications. Some candidate topologies with their advantages and drawbacks are presented in the following section. 
TABLE II

COMPARISON OF ELECTROLYZER TECHNOLOGIES

\begin{tabular}{|c|c|c|c|}
\hline & Alkaline & PEM & SO \\
\hline Advantages & $\begin{array}{l}\text { - Mature technology } \\
\text { - Long-term stability } \\
\text { - High durability and gas purities } \\
\text { - Cheaper catalyst } \\
\text { - Stacks in the MW range }\end{array}$ & $\begin{array}{l}\text { - High current densities } \\
\text { - High voltage efficiency } \\
\text { - Fast system response } \\
\text { - Compactness } \\
\text { - High gas purity } \\
\text { - Dynamic operation }\end{array}$ & $\begin{array}{l}\text { - High gas purity } \\
\text { - High efficiency } \\
\text { - Possible reversibility: operation in fuel } \\
\text { cell mode }\end{array}$ \\
\hline Drawbacks & $\begin{array}{l}\text { - Low current densities } \\
\text { - Crossover gases } \\
\text { - Low partial load range } \\
\text { - Load dynamics } \\
\text { - Low operational pressures } \\
\text { - Corrosive liquid electrolyte } \\
\text { - Low tolerance to impurities in the } \\
\text { water }\end{array}$ & $\begin{array}{l}\text { - High cost of components } \\
\text { - Technology relatively new } \\
\text { - Acidic corrosive environment } \\
\text { - Limited durability } \\
\text { - Low tolerance to impurities in } \\
\text { the water }\end{array}$ & $\begin{array}{l}\text { - Not commercially available (under } \\
\text { research and development) } \\
\text { - Fragility of materials } \\
\text { - Need for a significant heat input } \\
\text { - Limited lifetime of ceramics } \\
\text { - Long start-up time }\end{array}$ \\
\hline
\end{tabular}

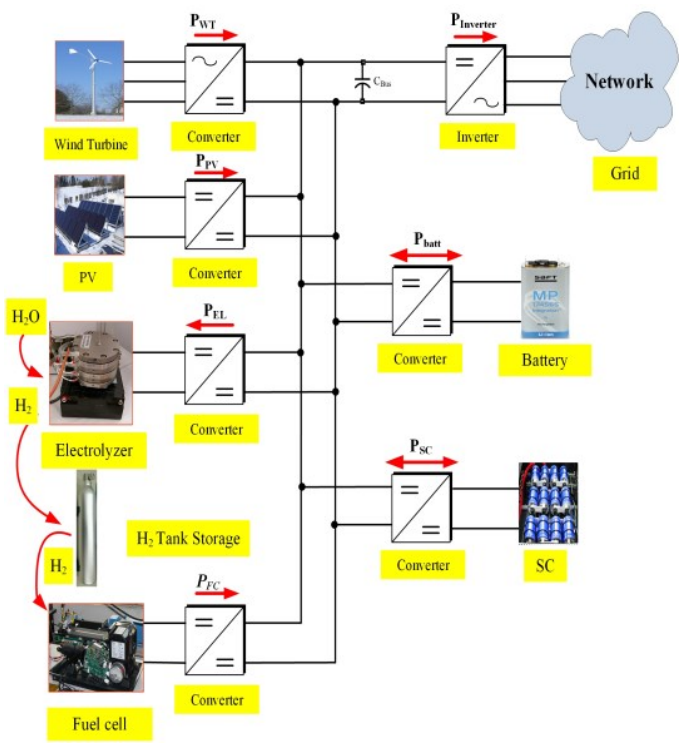

Fig. 1. Hybrid renewable energy system with a hydrogen buffer storage based on a DC bus configuration.

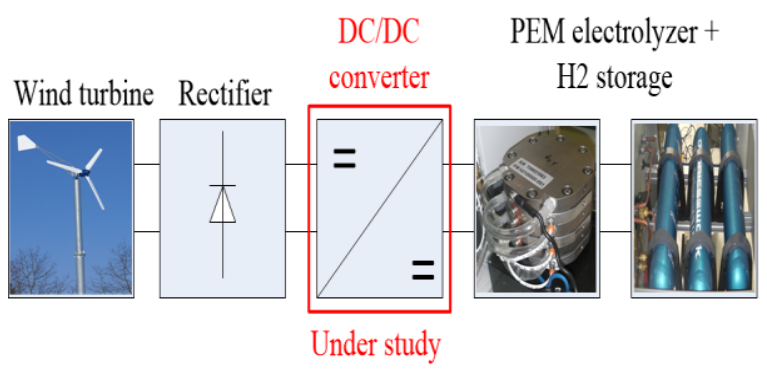

Fig. 2. Hydrogen generation pathways from wind turbines.

\section{CANDidATE INTERLEAVED DC/DC STEP-DOWN CONVERTERS}

\section{A. Interleaved buck converter}

Based on the classic buck converter, interleaved buck converters can be achieved. These topologies are built by connecting in parallel $\mathrm{N}$ buck converters (from $\mathrm{N}=2$ to $\mathrm{N}=6$ ) with a common DC bus [4]. They present several benefits compared to the classic buck converter, especially from energy efficiency, output current ripple reduction and reliability point of view [4]. Generally, a three-leg interleaved buck converter (IBC) is preferred for optimization reasons (i.e. magnetic component size, output current ripple, energy efficiency) as shown in Fig. 3.

However, IBC topologies present the following drawbacks [4]:

1) Large voltage stresses at the terminals of power switches and diodes (limited energy efficiency).

2) Medium conversion ratio (not suitable for electrolyzers requiring a high voltage ratio).

Over the last decade, many improvements have been brought to the classic IBC, especially from voltage ratio and energy efficiency point of view. These important issues can be solved by modifying the architecture and/or using coupled inductors. In the next subsections, several candidates interleaved buck topologies are presented with the improvements brought to the classic IBC.

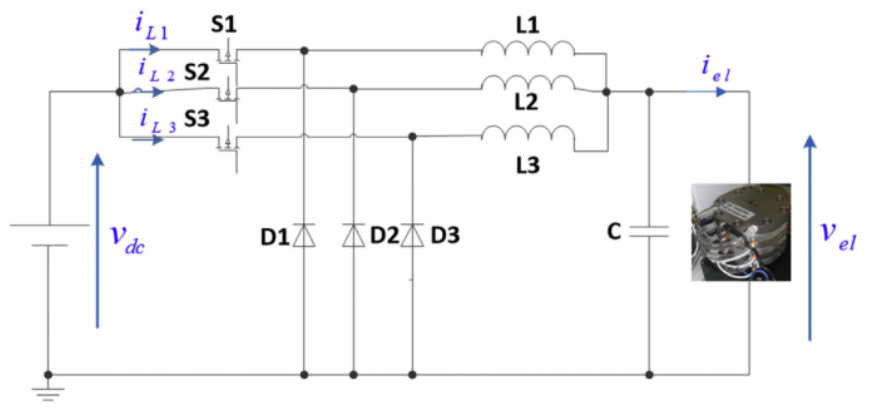

Fig. 3. IBC connected with the electrolyzer.

B. Interleaved buck converters with a single-capacitor snubber

The first topology (Fig. 4) differs from the conventional IBC topology for two aspects [9]:

1. a single-capacitor snubber that consists of a resonant capacitor $C_{1}$ and either inductor $L_{1}$ or $L_{2}$;

2. an EI core thanks to which the two coupled inductors ( $L_{1}$ and $L_{2}$ ) are designed. 
The snubber circuit is employed to minimize turn-off losses, switching losses and number of components as well. In addition, it allows limiting the rising rate of the voltage at the terminals of the power switch.

The magnetic core (i.e. EI) is employed to decrease the volume of the converter. Besides, to optimize energy efficiency, the inverse coupling method is used for $L_{l}$ and $L_{2}$ that leads to better stationary and dynamic performance.

On the one hand, this converter features the same dynamic performance of the classic IBC. On the other hand, IBCs with a single-capacitor snubber can lead up to higher efficiency than conventional IBC for applications requiring a low voltage ratio; whereas for high voltage ratio, the two converters produce approximately the same efficiency.

The voltage ratio of the converter according to the duty cycle $D$ is given by the following equation [9]:

$$
\frac{V_{o}}{V_{i}}=\frac{(1-D+k D) 3 D^{2}}{(7 k-3) D^{2}-(5 k-3) D+k}
$$

where:

- the coupling coefficient $k(k=M / L)$ of the coupled inductors $L_{1}$ and $L_{2}$ is considered equal to 0.33 [9];

- $\quad M$ is the mutual inductance;

the coupled inductors are made with a symmetric structure $\left(L_{l}\right.$ $=L_{2}=L$ ).

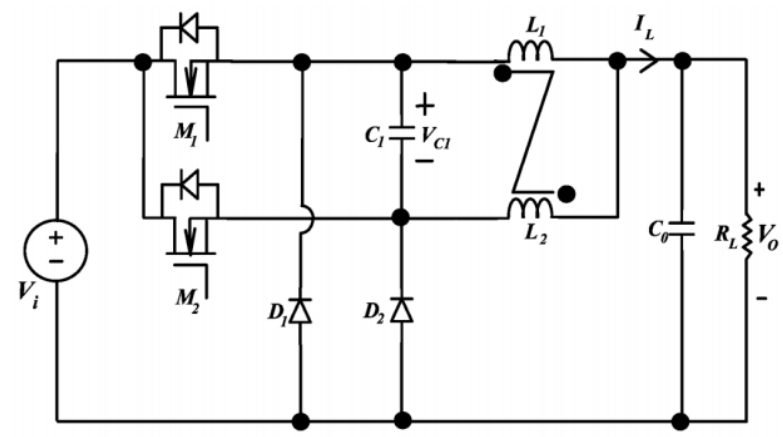

Fig. 4. IBC with a single-capacitor snubber [9].

\section{Interleaved buck converter with coupled windings}

Compared to the previous topology, the second topology (Fig. 5) is composed of the following elements [10]:

1. two windings coupled with a transformation ratio $n$, connected to each phase of the converter. Each winding is coupled with the inductance of the corresponding phase;

2. a synchronous IBC composed of two phases.

The addition of the two windings situated before the classic interleaved structure leads to a new topology. It significantly enhances energy efficiency without deteriorating the dynamic response of the converter. Furthermore, it proposes an improved voltage ratio, given by the following expression [10]:

$$
\frac{V_{o}}{V_{\text {in }}}=\frac{D}{n+1}
$$

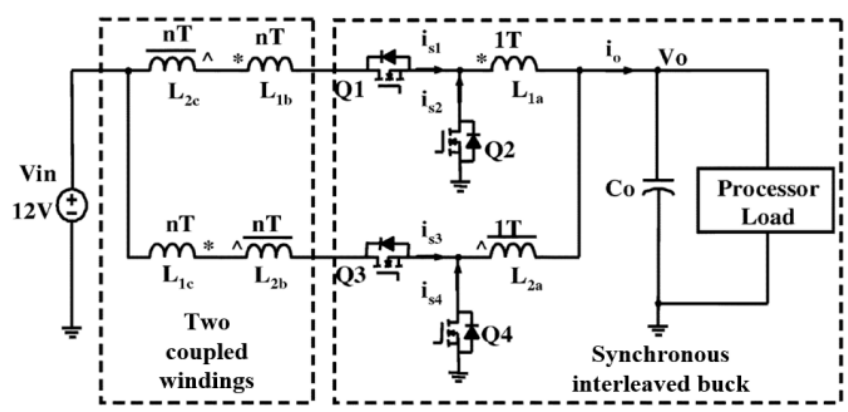

Fig. 5. IBC with coupled windings [10].

\section{Interleaved three-level buck converter}

The interleaved architecture (Fig. 6) is a three-level DC-DC converter.

In multilevel DC-DC converters, each power switch must withstand only a part of the input voltage and this allows operation with input voltages that are higher than the ratings of the power switches [11].

This topology consists of two interleaved buck converters, each of which includes [11]:

1. the main inductor $L_{0} / 2$;

2. two commutation inductors $\left(L_{1}, L_{2}\right.$ or $\left.L_{3}, L_{4}\right)$.

The four auxiliary inductors $\left(L_{1}, L_{2}, L_{3}, L_{4}\right)$ allow an important decrease of the power losses related to diode reverse recovery and turn-on transitions at no current.

The interleaved ZCT TL topology is addressed to high-power, high-voltage applications. Furthermore, it can be observed that [11]:

- it can operate at high switching frequencies and this makes easier the design of the output filter;

- all power switches play a part in the power management of the topology and equally divide the electrical power;

- the volume of the converter can be minimized by using coupled inductors.

The converter must operate at duty cycle values smaller than 0.5 permitting the diodes to switch. Otherwise, if the duty cycle is higher than 0.5 , the soft switching feature will not be ensured. The conversion gain of the converter is obtained by the following equation [11]:

$$
\frac{V_{O}}{V_{\text {in }}}=\frac{2 D}{1+\frac{2 R_{e}}{R_{O}}}
$$

where:

- $R_{e}$ is the lossless resistance $\left(R_{e}=2 L_{c} / T_{s}\right)$;

- $T_{s}$ is the switching period;

- $L_{c}$ is the commutation inductance (if $L_{1}=L_{2}=L_{3}=L_{4}$ $=L$ : without coupled inductors, $L_{c}=2 L$, instead of with coupled inductors, $L_{c}=4 L$ );

- $R_{o}$ is the output load resistance. 


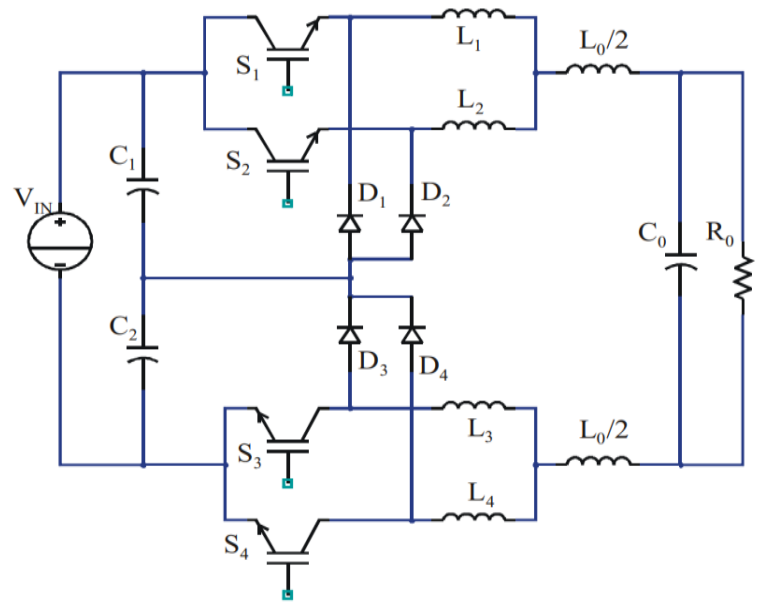

Fig. 6. Interleaved zero current transition (ZCT) three-level (TL) buck converter [11].

\section{E. Interleaved zero-current-transition buck converter}

The topology (Fig. 7) is an interleaved ZCT buck converter. It differs from the conventional topology since there is an output inductance $L_{o}$.

The auxiliary inductors $L_{1}$ and $L_{2}$ set the current slopes during the switching phases. As the result, these inductors impact the losses related to diode reverse recovery issues. Furthermore, the additional turn-on losses, related to the amount of the leakage diode current, can be guided by the appropriate choice of the auxiliary inductors. The larger the magnetic components $\left(L_{I}\right.$ and $L_{2}$ ), the smaller the reverse recovery and leakage currents. However, the switching times last longer and therefore it is needed to find a compromise [12]. Moreover, these auxiliary magnetic components enable ZCT turn-on.

The output inductor $L_{o}$, which is larger than the inductors $L_{l}$ and $L_{2}$, allows operating at a continuous conduction mode with low output current ripple.

The two power switches contribute towards the power management of the converter. Hence, it makes easier the thermal design and leads to a significant reduction of losses.

Finally, the conversion gain of the converter is provided by the following equation [12]:

$$
\frac{V_{o}}{V_{\text {in }}} \approx 2 D
$$

Equation (4) clearly emphasizes that the complete range of conversion gains $\left(0<V_{o} / V_{i n}<1\right)$ can be achieved by operating each power switch with a duty cycle value included between 0 and 0.5 [12].

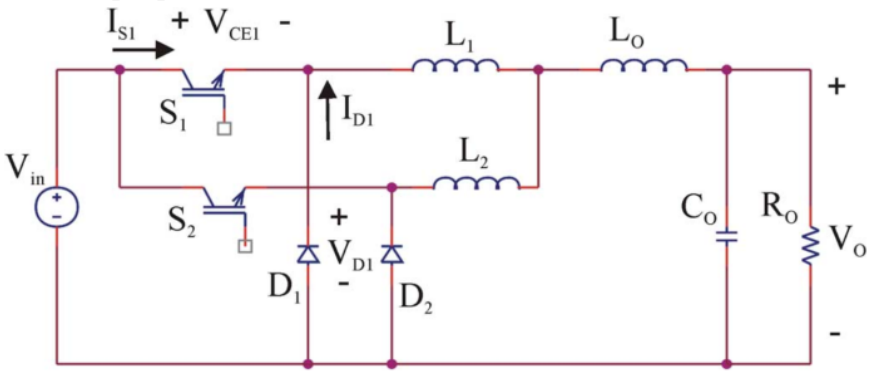

Fig. 7. Interleaved zero-current-transition (ZCT) buck converter [12].

\section{F. Stacked interleaved converter}

The converter (Fig. 8) is the stacked interleaved topology and it differs from the conventional topology since there is a capacitor $\left(C_{S}\right)$ in the secondary phase.

The capacitor located in the second phase $\left(C_{S}\right)$ stops from flowing the continuous load current from the second phase, making the continuous current for the first phase. This aspect is useful for practical applications where the magnetic components have various parasitic resistances leading up to increasing losses in the secondary phase [13].

The first advantage of the stacked interleaved topology is that it allows a full suppression of the output current ripple whatever the duty cycle values, reducing the needed phases to two (unlike conventional IBC topologies where the number of cancellations strongly depends on the duty cycle and the number of phases).

This current ripple cancellation is achieved through the following components and operation [13]:

- the first phase $\left(S_{P}, L_{P}, C_{P}\right)$ connected with the load and operating with a duty cycle $D$;

- the second phase $\left(S_{S}, L_{S}, C_{S}\right)$ no connected with the load and operating with a duty cycle 1-D;

and with the timing chart shown in Fig. 8 .

Eliminating the output current ripple, it allows removing the relation between the current ripple of the inductors $\left(L_{P}\right.$ and $\left.L_{S}\right)$ and the output voltage ripple. As a result, the inductors are smaller than inductors met in IBC. Additionally, the volume reduction of inductors brings more compactness and enhances the dynamic response of the topology.

Connecting the two phases together through a capacitor $\left(C_{S}\right)$, it allows obtaining two different voltages. Indeed, the voltage ratios of the converter are given by the following expressions, respectively for the first and second phase [13]:

$$
\frac{V_{\text {OUT }}}{V_{I N}}=D
$$

and

$$
\frac{V_{O U T}}{V_{I N}}=1-D
$$

The stacked interleaved topology allows coupling the two inductors $L_{P}$ and $L_{S}$. In this case, this coupling permits the reduction of the volume of the inductance, and the attenuation of the current ripple flowing through each inductor.

Therefore, by reducing the current ripple, energy efficiency is improved. In addition, another advantage of using magnetic coupling is the area reduction by stacking the inductors [13].

Finally, as highlighted in [13], all the process effects occurring in a practical implementation, the non-idealities of the converter bring about a delay between the switching transitions. Any overlaps lead up to high current ripples depending on the gain of the magnetic coupling and the duration of the overlaps. The higher the current ripple, the lower the energy efficiency of the converter. In summary, the gain of magnetic coupling has to be chosen judiciously to reduce the effects of time errors [13]. 


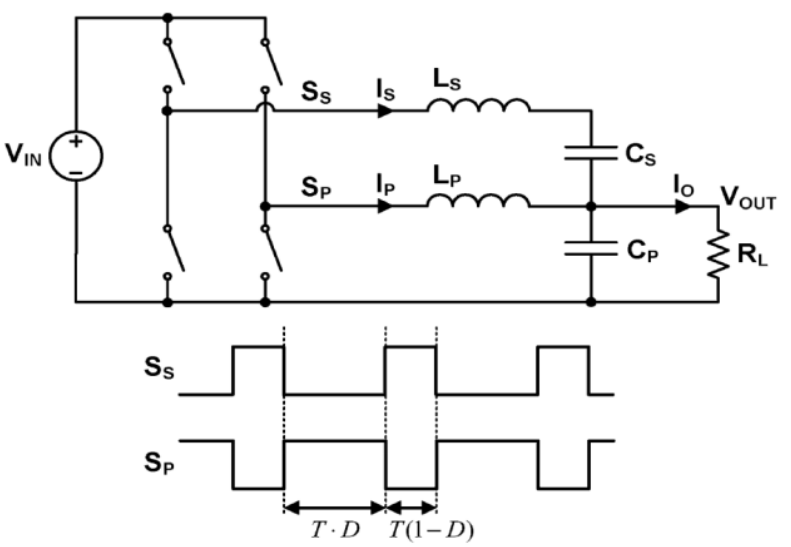

Fig. 8. Stacked interleaved topology and timing chart [13].

G. Interleaved buck converter with winding-cross-coupled inductors and passive-lossless clamp scheme

The topology depicted in Fig. 9 differs from the conventional IBC topology for two aspects:

1. a basic cell with WCCIs and interleaved architecture;

2. a passive-lossless clamp circuit.

The basic cell has two WCCIs $\left(L_{1}\right.$ and $\left.L_{2}\right)$. Each WCCI has three windings $\left(L_{1 a}, L_{1 b}, L_{2 c}\right.$ and $\left.L_{2 a}, L_{2 b}, L_{1 c}\right)$. The second winding with $n_{2}$ turns is linked with the winding in its phase with $n_{1}$ turns ( $L_{1 b}$ versus $L_{1 a}$ and $L_{2 b}$ versus $L_{2 a}$ ) and the third winding with $n_{2}$ turns is linked with the windings in another phase ( $L_{1 c}$ versus $L_{1 a}$ and $L_{1 b}, L_{2 c}$ versus $L_{2 a}$ and $L_{2 b}$ ) [14]. The first windings $L_{1 a}$ and $L_{2 a}$ have similar features as the magnetic components in the basic IBC. The second and the third windings $\left(L_{1 b}, L_{1 c}\right.$, and $\left.L_{2 b}, L_{2 c}\right)$ are used as continuous voltage sources and are in series in the circuit to alleviate the power switch voltage stress [14]. Moreover, the use of these windings allows achieving high step-down voltage ratios [14].

The basic cell takes advantage of:

- the basic interleaved structure to decrease the current ripple, which reduces the inductor size, increases the power level and enhances the dynamic response;

- the coupled inductors to obtain a high conversion gain. They aim also at reducing the power switch voltage stress and at avoiding the reduced turnoff pulse operation, which decreases the conduction losses and the current ripple.

On the other side, the fact of using WCCIs leads up to leakage inductances $\left(L_{L k 1}\right.$ and $\left.L_{L k 2}\right)$, which result in large switching losses, high voltage spikes, and serious electromagnetic interference (EMI) issues [14].

The drawbacks caused by WCCIs can be solved by means of the passive-lossless clamp circuit. The passive-lossless circuit, consisting of two clamp capacitors $\left(C_{c l}\right.$ and $\left.C_{c 2}\right)$ and four clamp diodes $\left(D_{c 11}, D_{c 12}, D_{c 21}, D_{c 22}\right)$, absorbs the voltage spikes on the power switch and reuses the leakage energy [14]. As a result, the energy efficiency of the topology is enhanced, and the electromagnetic disturbances noise is canceled [14].
Compared with the classic IBC, this converter allows decreasing the power switch voltage stress due to the features of the WCCIs. Furthermore, high-performance power semiconductors with low on-state resistances can be used to decrease the conduction losses [14]. The reverse-recovery issue of the output diode $\left(D_{o l}, D_{o 2}\right)$ is mitigated and the reverserecovery losses are minimized given that the output diode current falling rate is imposed by the leakage inductance [14].

In summary, this converter is fit for high power applications, high current, high step-down conversion, and to operate at a high switching frequency.

Finally, the conversion gain of the converter is obtained by using this following equation [14]:

$$
\frac{V_{\text {out }}}{V_{\text {in }}}=\frac{D}{N+1}
$$

where:

- $\quad D \leq 0.5$;

- $\quad N$ is the turns ratio $\left(N=n_{2} / n_{1}\right)$.

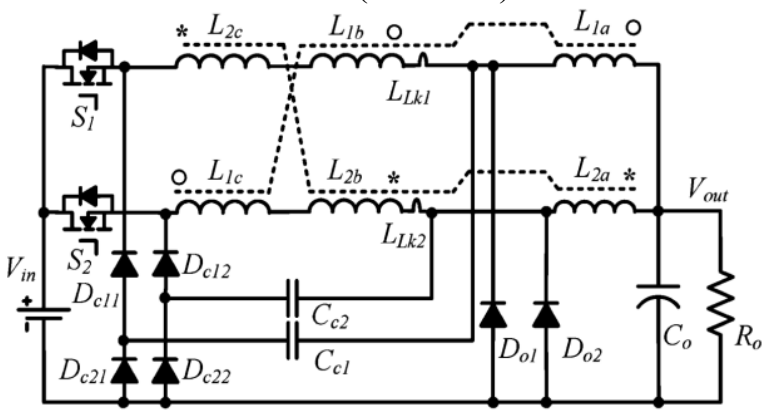

Fig. 9. Interleaved DC-DC high step-down buck converter with winding-crosscoupled inductors (WCCIs) and passive-lossless clamp scheme [14].

\section{$H$. Interleaved coupled-buck converter with active-clamp circuits}

By comparison, this topology (Fig. 10) differs from the conventional topology for these three aspects [15]:

1. two coupled windings on each phase ( $L_{11}$ and $L_{1}, L_{22}$ and $L_{2}$ with transformation ratios, respectively indicated $n_{1}$ and $n_{2}$ );

2. a resonance inductance per phase $\left(L_{r l}\right.$ and $\left.L_{r 2}\right)$;

3. an active-clamp circuit per phase ( $M_{11}$ and $C_{r l}, M_{22}$ and $\left.C_{r 2}\right)$.

On the one hand, resonant inductors are used to achieve zero voltage switching for the main and auxiliary power switches, and to limit transient reverse currents of freewheeling diodes. Hence, it allows reducing significantly reverse-recovery losses. On the other hand, the active-clamp circuits allow recovering the dispersion energy and limiting the voltage spikes [15].

Like the previous topology, the use of coupled windings allows improving the voltage gain of the converter, provided by the equation (8) [15]:

$$
\frac{V_{o}}{V_{i}}=\frac{D}{D+n(1-D)}
$$




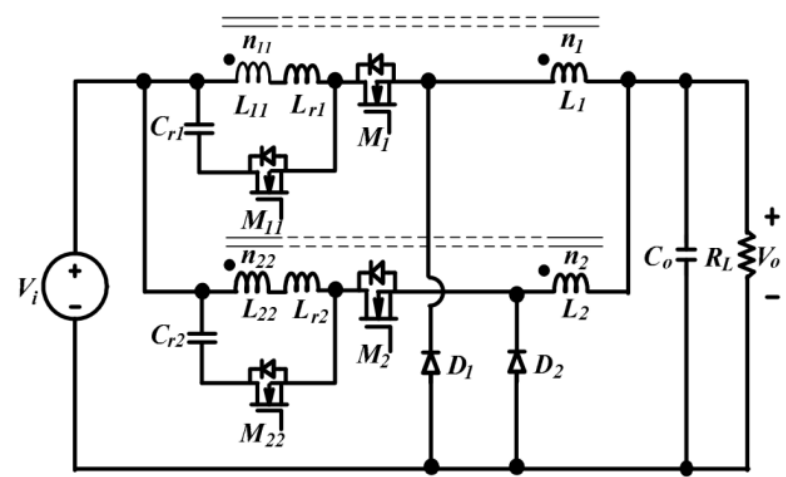

Fig. 10. Interleaved coupled-buck converter with active-clamp circuits [15].

\section{Interleaved buck converter with extended duty cycle}

The interleaved architecture of Fig. 11 is similar to the conventional IBC, but it differs for two aspects [16]:

1. two active switches, $Q_{1}$ and $Q_{2}$, are connected in series;

2. a coupling capacitor $\left(C_{B}\right)$ is employed in the power path (it is quite large to be regarded as a voltage source).

The IBC topology with extended duty cycle is particularly suitable for high input voltage applications where the operating duty cycle must be less than or equal to 0.5 .

The converter of Fig. 11 presents the following advantages than the conventional IBC [16]:

- a higher step-down conversion ratio;

- a smaller output current ripple (therefore, the inductors with a smaller inductance can be used).

Moreover, the main advantage of this topology is that since the voltage stress across active switches $\left(Q_{1}\right.$ and $\left.Q_{2}\right)$ is half of $V_{S}$ before turn-on or after turn-off when the operating duty cycle is below $50 \%$, the capacitive discharging and switching losses can be reduced substantially; this allows the converter of Fig. 11 to have a higher efficiency than that of the conventional IBC and operate with higher switching frequencies.

The conversion gains of the IBC topology with extended duty cycle are obtained by the following equations [16]:

$$
\left.\frac{V_{O}}{V_{S}}=\frac{D}{2} \quad \text { (with } D \leq 0.5\right)
$$

and

$$
\left.\frac{V_{O}}{V_{S}}=D^{2} \quad \text { (with } D>0.5\right)
$$

Finally, we observe that the voltage stress of $D_{l}$, during the cold startup, could be higher than $V_{S}$. To solve this issue, an auxiliary circuit can be added to the input stage of the converter (Fig. 12).

This auxiliary circuit is composed of:

- two capacitors $\left(C_{a d d l}, C_{a d d 2}\right)$;

- a diode $\left(D_{\text {add }}\right)$;

- a resistor $\left(R_{\text {add }}\right)$; it has the goal of absorbing transient energy generated by parasitic elements during the cold startup.

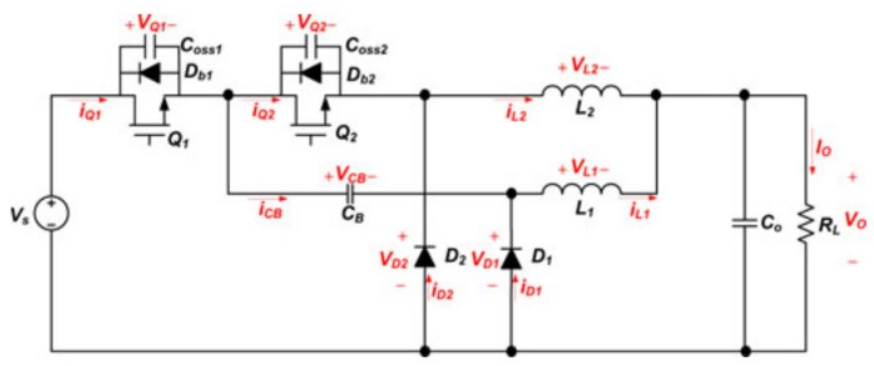

Fig. 11. IBC with extended duty cycle [16].

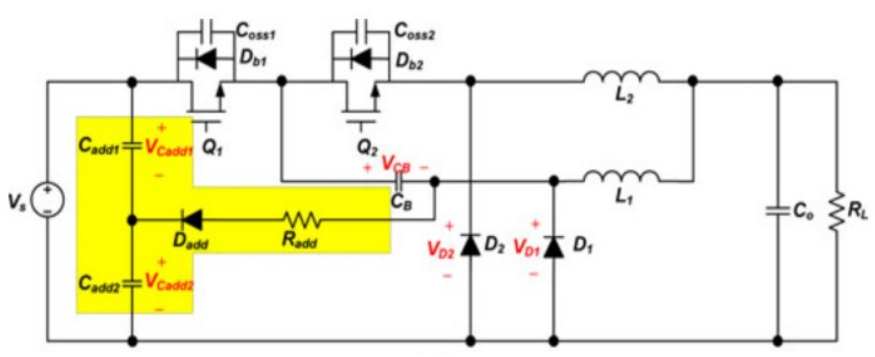

Fig. 12. IBC with extended duty cycle and auxiliary circuit [16].

\section{COMPARISON OF CANDIDATE INTERLEAVED STEP-DOWN CONVERTERS}

As highlighted in a previous review work [4], three types of DC-DC converters are currently used for PEM EL applications, such as buck, half-bridge, and full-bridge DC-DC converters. However, these classic converters are not optimized from voltage ratio, energy efficiency, output current ripple minimization, and availability point of view. In this article, only interleaved step-down converters have been considered due to their advantages for PEM EL applications. On the one hand, the interleaved step-down converters [9,10], [12-16] are composed of two phases. Despite these topologies are fault-tolerant in case of electrical failures, if one of the phases was faulty, the converter would lose its features [4]. On the other hand, interleaved three-level step-down converter offers an enhanced availability in case of electrical failures [11]. Indeed, this converter is composed of two phases in the non-floating part (upper) and two phases in the floating part (lower). If one of the phases was faulty, the converter could continue to operate without any operation. However, with the aim to improve and optimize the operation of the converter, fault-tolerant strategies must be applied after fault identification and detection.

Availability in the case of electrical failures is not the only requirement for PEM EL. Indeed, one of the most important requirements is a high conversion gain since the PEM EL must be supplied with a very low DC voltage. Furthermore, a low output current ripple (both low and high frequency) is required to optimize PEM EL performance, especially from energy efficiency and hydrogen production point of view. Hence, a thorough analysis of the conversion gain and current ripples is provided in Table III for each interleaved step-down converter. Besides, Fig. 13 shows a comparison between conversion gain according to the duty cycle. 
TABLE III

COMPARISON OF INTERLEAVED STEP-DOWN CONVERTERS FROM CONVERSION GAIN AND CURRENT RIPPLE POINT OF VIEW

\begin{tabular}{|c|c|c|c|c|c|}
\hline TOPOLOGY & \multirow{2}{*}{\multicolumn{2}{|c|}{$\begin{array}{l}\text { CONVERSION GAIN } \\
\frac{v_{e l}}{v_{d c}}=D\end{array}$}} & \multicolumn{2}{|c|}{ PHASE CURRENT RIPPLE } & OUTPUT CURRENT RIPPLE \\
\hline IBC [4] & & & \multicolumn{2}{|c|}{$\begin{array}{l}\text { For the first, second and third phase: } \\
\Delta I_{L}=\frac{v_{e l}(1-D)}{L f_{s w}} \\
\text { with: } \\
L_{1}=L_{2}=L_{3}=L\end{array}$} & $\begin{array}{rlrl}\Delta I & =\frac{v_{e l} D(1-3 D)}{L f_{s w}} & , & 0<D<\frac{1}{3} \\
\Delta I=\frac{v_{e l}(3 D-1)(2-3 D)}{3 L f_{s w}} & , & \frac{1}{3}<D<\frac{2}{3} \\
\Delta I=\frac{v_{e l}(3 D-2) D}{L f_{s w}} & , & \frac{2}{3}<D<1\end{array}$ \\
\hline $\begin{array}{l}\text { IBC with a } \\
\text { single-capacitor } \\
\text { snubber [9] }\end{array}$ & \multicolumn{2}{|c|}{$\frac{V_{o}}{V_{i}}=\frac{(1-D+k D) 3 D^{2}}{(7 k-3) D^{2}-(5 k-3) D+k}$} & \multicolumn{2}{|c|}{$\begin{array}{l}\text { For the first and second phase: } \\
\Delta I=\left(V_{i}-V_{o}\right) \frac{[L(1-D)+M \cdot D]^{2}}{L\left(L^{2}-M^{2}\right)(1-D)^{2}} \cdot \frac{D}{f_{S W}} \\
\text { where: } \\
0<D \leq \frac{1}{2} \\
M: \text { mutual inductance } \\
L_{I}=L_{2}=L\end{array}$} & $\begin{array}{l}\Delta I_{L}=\frac{D(L-M)\left(V_{i}-V_{o}\right)[L(1-D)+M D]^{2}-V_{o} L D\left(L^{2}-M^{2}\right)(1-D)^{2}}{L^{2}\left(L^{2}-M^{2}\right)(1-D)^{2} f_{S w}} \\
\text { where: } \\
0<D \leq \frac{1}{2} \\
M: \text { mutual inductance } \\
L_{I}=L_{2}=L\end{array}$ \\
\hline $\begin{array}{l}\text { IBC with } \\
\text { coupled } \\
\text { windings [10] }\end{array}$ & \multicolumn{2}{|c|}{$\begin{array}{l}\frac{V_{o}}{V_{i n}}=\frac{D}{n+1} \\
n: \text { turns of coupled windings }\end{array}$} & \multicolumn{2}{|l|}{ There is not. } & $\begin{array}{l}\Delta I_{o}=\frac{V_{i n}-(n+1) V_{o}}{L_{e q}} \cdot \frac{D}{f_{s w}}=\frac{(1-D)(n+1) V_{o}}{L_{e q}} \cdot \frac{1}{f_{s w}} \\
\text { where: } \\
L_{e q}=L_{l b}+L_{l a}+2 M \\
M: \text { mutual inductance }\end{array}$ \\
\hline $\begin{array}{l}\text { Interleaved } \\
\text { ZCT TL buck } \\
\text { converter [11] }\end{array}$ & \multicolumn{2}{|l|}{$\frac{V_{o}}{V_{i n}}=\frac{2 D}{1+\frac{2 R_{e}}{R_{o}}}$} & \multicolumn{2}{|l|}{ There is not. } & $\begin{array}{l}\Delta I_{L_{0}}=\frac{V_{o}(1-4 D)}{L_{0} f_{s w}}, \quad 0<D<\frac{1}{4} \\
\Delta I_{L_{0}}=\frac{V_{o}(4 D-1)(2-4 D)}{4 D L_{0} f_{s w}}, \quad \frac{1}{4}<D<\frac{1}{2} \\
\text { where: } \\
L_{0} \gg L_{c} \\
L_{c}: \text { commutation inductance. } \\
L_{1} \text { and } L_{2}: \text { two small commutation inductors for } \\
\text { the IBC connected to the positive voltage rail. } \\
L_{3} \text { and } L_{4}: \text { two small commutation inductors for } \\
\text { the IBC connected to the negative voltage rail. } \\
L_{c}: \text { sum of the commutation inductors in each of } \\
\text { the two IBCs. }\end{array}$ \\
\hline $\begin{array}{l}\text { Interleaved } \\
\text { ZCT buck } \\
\text { converter [12] }\end{array}$ & \multicolumn{2}{|l|}{$\frac{V_{o}}{V_{\text {in }}} \approx 2 D$} & \multicolumn{2}{|l|}{ There is not. } & $\begin{array}{l}\Delta I_{L_{o}}=\frac{V_{i n}-V_{o}}{L+L_{o}} \cdot \frac{D}{f_{s w}} \\
\text { where: } \\
0<D \leq \frac{1}{2}\end{array}$ \\
\hline \multirow[t]{2}{*}{$\begin{array}{l}\text { Stacked } \\
\text { interleaved } \\
\text { converter [13] }\end{array}$} & \multirow[t]{2}{*}{$\begin{array}{l}\text { For first } \\
\text { phase: } \\
\frac{V_{\text {OUT }}}{V_{I N}}=D \\
\text { where: } \\
0<D<1\end{array}$} & \multirow[t]{2}{*}{$\begin{array}{l}\text { For second } \\
\text { phase: } \\
\frac{V_{\text {OUT }}}{V_{I N}}=1-D \\
\text { where: } \\
0<D<1\end{array}$} & $\begin{array}{l}\text { For the first phase } \\
\text { (without magnetic } \\
\text { coupling between the } \\
\text { inductors): } \\
\Delta I_{P}=(1-D) D \frac{V_{I N}}{L f_{S w}} \\
\text { where: } \\
0<D<1 \\
L_{S}=L_{P}=L\end{array}$ & $\begin{array}{l}\text { For the second phase } \\
\text { (without magnetic coupling } \\
\text { between the inductors): } \\
\Delta I_{S}=-(1-D) D \frac{V_{I N}}{L f_{s w}} \\
\text { where: } \\
0<D<1 \\
L_{S}=L_{P}=L\end{array}$ & $\begin{array}{l}\text { Complete ripple cancellation across all duty } \\
\text { cycles }(0<D<1)\end{array}$ \\
\hline & & & $\begin{array}{l}\text { For the first phase } \\
\text { (with magnetic coupling } \\
\text { between the inductors): } \\
\Delta I_{P}= \\
=\frac{1}{L(1+k)} D(1-D) V_{I N} \frac{1}{f_{s w}} \\
\text { where: } \\
0<D<1 \\
L_{S}=L_{P}=L \\
k=\frac{M}{L} \\
k: \text { mutual coupling factor } \\
M: \text { mutual inductance }\end{array}$ & $\begin{array}{l}\text { For the second phase } \\
\text { (with magnetic coupling } \\
\text { between the inductors): } \\
\Delta I_{S}= \\
=-\frac{1}{L(1+k)} D(1-D) V_{I N} \frac{1}{f_{S W}} \\
\text { where: } \\
0<D<1 \\
L_{S}=L_{P}=L \\
k=\frac{M}{L} \\
k: \text { mutual coupling factor } \\
M: \text { mutual inductance }\end{array}$ & $\begin{array}{l}\text { Complete ripple cancellation across all duty } \\
\text { cycles }(0<D<1)\end{array}$ \\
\hline $\begin{array}{l}\text { IBC with } \\
\text { WCCIs and } \\
\text { passive-lossless } \\
\text { clamp scheme } \\
{[14]}\end{array}$ & \multicolumn{2}{|l|}{$\begin{array}{l}\frac{V_{\text {out }}}{V_{\text {in }}}=\frac{D}{N+1} \\
N=\frac{n_{2}}{n_{1}}\end{array}$} & \multicolumn{2}{|l|}{ There is not. } & $\begin{array}{l}\Delta I_{\text {out }}=\frac{V_{\text {in }}-(N+1) V_{\text {out }}}{L_{e q}} \cdot \frac{D}{f_{\text {sw }}}=\frac{(1-D)(N+1) V_{\text {out }}}{L_{e q}} \cdot \frac{1}{f_{\text {sw }}} \\
\text { where: } \\
0<D \leq \frac{1}{2} \\
L_{e q}=L_{l b}+L_{l a}+2 M\end{array}$ \\
\hline
\end{tabular}


TABLE III

(CONTINUATION)

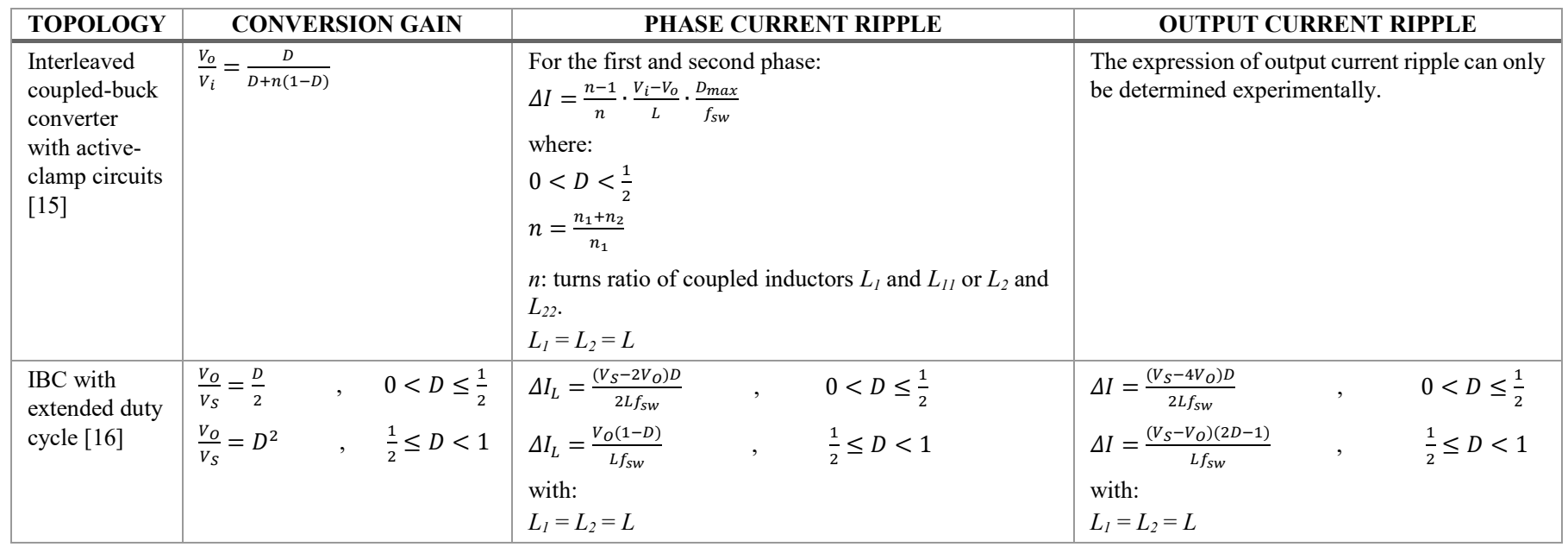

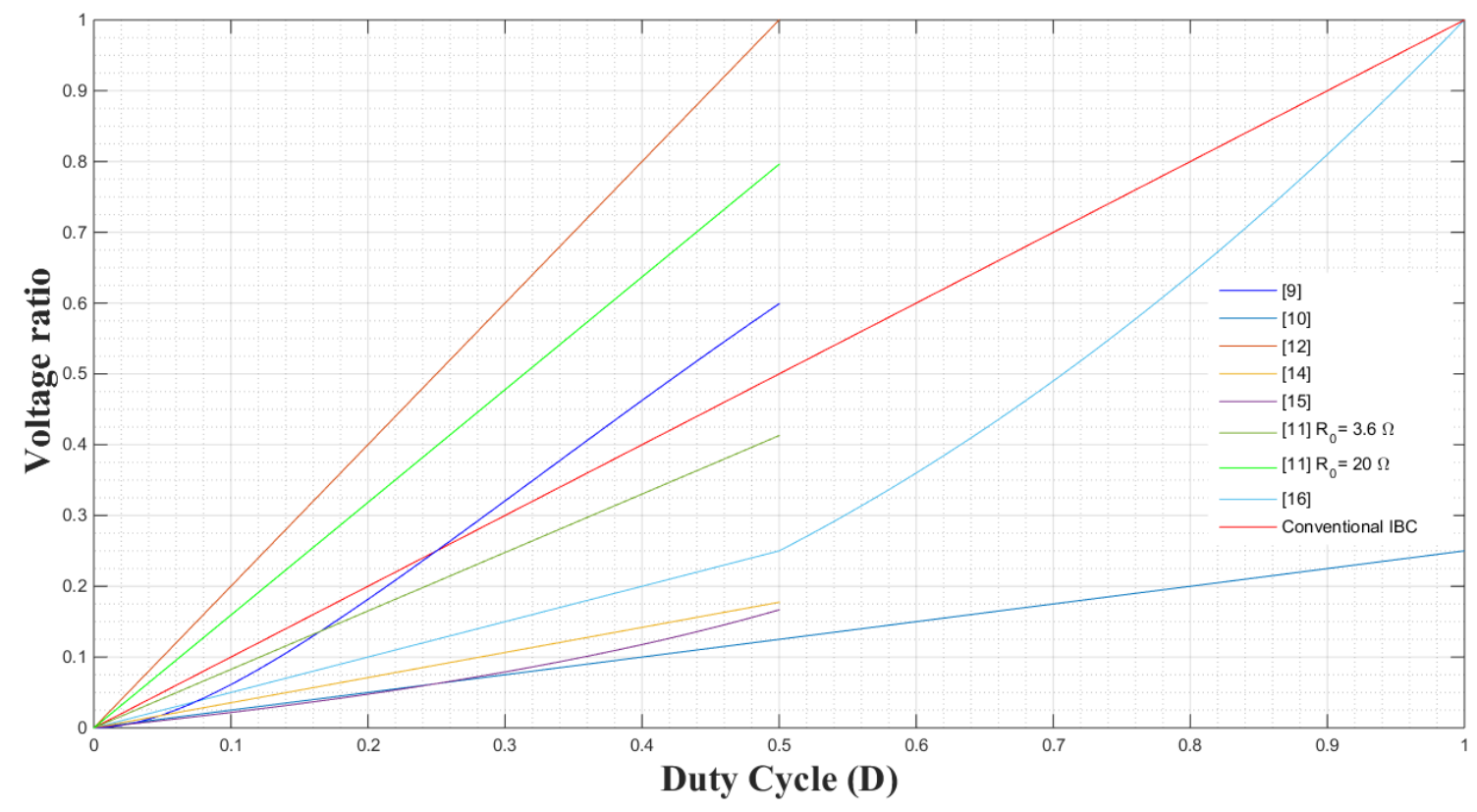

Fig. 13. Comparison of the voltage ratio according to the duty cycle.

Based on Table III and Fig. 13, it can be observed that the classic IBC is not fit for electrolyzers requiring a high voltage gain despite the output current ripples are strongly reduced compared to a classic step-down converter. Indeed, high voltage gain for an IBC leads up to operate at a very low duty cycle [4]. In addition, the most suitable converters for high voltage gain are IBC with coupled windings, IBC high stepdown with WCCIs and passive-lossless clamp circuit and interleaved coupled-buck converter with active-clamp circuits. These converters are very interesting for systems based on hydrogen buffer where wind turbines are used. By comparison, the stacked interleaved converter allows canceling the output current ripple whatever the duty cycle value; whereas for IBC topologies, the output current ripple can be canceled for specific duty cycle values [4]. However, this topology suffers from having a low voltage ratio like the classic step-down converter. From output current ripple and availability point of view, the three-level interleaved step-down converter is the most interesting topology for hybrid renewable energy systems with hydrogen storage based on a DC bus configuration.

\section{CONCLUSION}

The main objective of this paper is to carry out a thorough literature survey focused on candidate interleaved step-down converters for proton exchange membrane electrolyzer applications. Based on the current literature, it was demonstrated that the classical topologies (e.g. buck, halfbridge, full-bridge) currently used for these applications present several drawbacks. Hence, interleaved DC-DC step-down converters offer several advantages over classical topologies and are promising for these applications.

Based on the classic interleaved DC-DC step-down topology, several candidates interleaved converters were introduced in this article. Each converter was thoroughly analyzed to 
determine current ripples and voltage gain expression. From the obtained expressions (summarized in a table and a figure), the most interesting and promising interleaved step-down converters were emphasized from output current ripple reduction and voltage gain point of view.

\section{REFERENCES}

[1] T.S. Uyar, D. Beşikci, Integration of hydrogen energy systems into renewable energy systems for better design of $100 \%$ renewable energy communities, International Journal of Hydrogen Energy, Vol. 42, Iss. 4, 2017, pp. 2453-2456.

[2] M. Carmo, D.L. Fritz, J. Mergel, D. Stolten, A comprehensive review on PEM water electrolysis, International Journal of Hydrogen Energy, Volume 38, Issue 12, 2013, Pages 4901-4934.

[3] Alexander Buttler, Hartmut Spliethoff, Current status of water electrolysis for energy storage, grid balancing and sector coupling via power-to-gas and power-to-liquids: A review, Renewable and Sustainable Energy Reviews, Volume 82, Part 3, 2018, Pages 2440-2454.

[4] D. Guilbert, S.M. Collura, A. Scipioni, DC/DC converter topologies for electrolyzers: State-of-the-art and remaining key issues, International Journal of Hydrogen Energy, Volume 42, Issue 38, 2017, Pages 2396623985.

[5] M.E. Sahin, H.I. Okumus, M.T. Aydemir, "Implementation of an electrolysis system with DC/DC synchronous buck converter", International Journal of Hydrogen Energy, vol. 39, iss. 13, p. 6802-6812, 2014.

[6] T. Zhou, B. François, M. El Hadi Lebbal, S. Lecoeuche, "Real-time emulation of a hydrogen-production process for assessment of an active wind-energy conversion system", IEEE Transactions on Industrial Electronics, vol. 56, iss. 3, p. 737-746, 2009.

[7] P. Thounthong, B. Davat, "Study of a multiphase interleaved step-up converter for fuel cell high power applications", Energy Conversion and Management, vol. 51, iss. 4, p. 826-832, 2010.

[8] A. Kolli, A. Gaillard, A. De Bernardinis, O. Bethoux, D. Hissel, Z. Khatir, "A review on DC/DC converter architectures for power fuel cell applications", Energy Conversion and Management, vol. 105, p. 716-730, 2015.

[9] Yaow-Ming Chen, Sheng-Yu Tseng, Cheng-Tao Tsai and Tsai-Fu Wu, "Interleaved buck converters with a single-capacitor turn-off snubber", IEEE Transactions on Aerospace and Electronic Systems, vol. 40, no. 3, pp. 954-967, July 2004.

[10] K. Yao, Y. Qiu, M. Xu and F. C. Lee, "A novel winding-coupled buck converter for high-frequency, high-step-down DC-DC conversion", IEEE Transactions on Power Electronics, vol. 20, iss. 5, p. 1017-1024, 2005.

[11] M. Ilic, B. Hesterman and D. Maksimovic, "Interleaved zero current transition three-level buck converter", in: proceedings of Twenty-First Annual IEEE Applied Power Electronics Conference and Exposition, p. $72-78,2006$

[12] M. Ilic and D. Maksimovic, "Interleaved Zero-Current-Transition Buck Converter", IEEE Transactions on Industry Applications, vol. 43, no. 6 , pp. 1619-1627, 2007.

[13] J. Wibben and R. Harjani, "A High-Efficiency DC-DC Converter Using $2 \mathrm{nH}$ Integrated Inductors", IEEE Journal of Solid-State Circuits, vol. 43, no. 4 , pp. 844-854, 2008.

[14] W. Li and X. He, "A Family of Interleaved DC-DC Converters Deduced From a Basic Cell With Winding-Cross-Coupled Inductors (WCCIs) for High Step-Up or Step-Down Conversions", IEEE Transactions on Power Electronics, vol. 23, no. 4, pp. 1791-1801, 2008.

[15] C. T. Tsai and C. L. Shen, "Interleaved soft-switching coupled-buck converter with active-clamp circuits", in: Proceedings of 2009 International Conference on Power Electronics and Drive Systems (PEDS), p. 1113-1118, 2009.

[16] I. Lee, S. Cho and G. Moon, "Interleaved Buck Converter Having Low Switching Losses and Improved Step-Down Conversion Ratio," in IEEE Transactions on Power Electronics, vol. 27, no. 8, pp. 3664-3675, Aug. 2012.

[17] D. Guilbert, B. Yodwong, W. Kaewmanee, P. Phattanasak, Power converters for hybrid renewable energy systems with hydrogen buffer storage: A short review, in: Proceedings of $6^{\text {th }}$ International Conference on Smart Grid (IEEE ICSMARTGRID), 2018, forthcoming.

[18] T. Arunkumari, V. Indragandhi, An overview of high voltage conversion ratio DC-DC converter configurations used in DC micro-grid architectures, Renewable and Sustainable Energy Reviews, Volume 77, 2017, Pages 670-687.

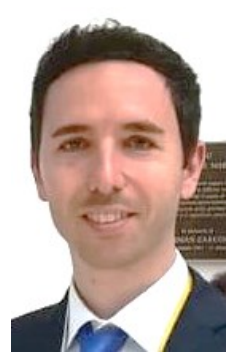

Vittorio Guida was born in Palermo (Italy) in 1984. After obtaining the high school Diploma as "Industrial Expert Technician Specialization Computer", at the "Istituto Tecnico Industriale Statale" of Palermo, he began his academic studies, at the University of Palermo, in Automation Engineering.

First, he obtained the Bachelor's degree with a thesis on the "Automatic Measurement System for the Testing of Electromagnetic Compatibility in Accordance with CEI EN 55014". Subsequently, he obtained the Master's degree with a thesis on the "Adaptive Control for Robotic Systems with Nonsingular Actuator Matrix".

During the academic path, he carried out internships to obtain the respective qualifications. In particular, in 2011, he worked at the "Molino e Pastificio Tomasello S.p.A.", for the implementation of a program in Matlab for image processing. In 2015, he carried out an internship at the University of California Riverside on the "Application of control-theoretic techniques to evaluate the difficulty of different cognitive control tasks, and design of advanced Brain-Computer Interfaces to facilitate the use of EEG signals and to control different dynamical systems".

In May/June 2017, he attended a Java programming course, organized by the QiBit Division (ICT Division of Gi Group S.p.A.), at their offices in Rome.

In October 2017, after passing an international competition, he was admitted to the Ph.D. program in Electrical Engineering, at the University of Lorraine in Longwy (France) with a Ph.D. thesis focused on "Design and realization of a DC/DC converter at high conversion ratio for electrolyzers".

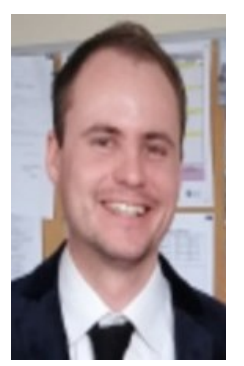

Damien GUILBERT was born in Paris, France, in 1987. He received the M.Sc. degree in electrical engineering and control systems and the Ph.D. degree in electrical engineering from the University of Technology of BelfortMontbéliard (UTBM), France, in 2011 and 2014 respectively. His current research interests include power electronics, fuel cell, and electrolyzer system, modeling and emulation of PEM electrolyzers, fault-tolerant DC/DC converters for fuel cell/photovoltaic/electrolyzer applications, and fault-tolerant control for fuel cell/electrolyzer systems. He was involved in the creation of the first IEEE/IAS student branch and chapter in France at UTBM, where he was the president in 2015. Since September 2016, he has been Associate Professor at Université de Lorraine and a permanent member of GREEN (Group of Research in Electrical Engineering of Nancy) laboratory. 


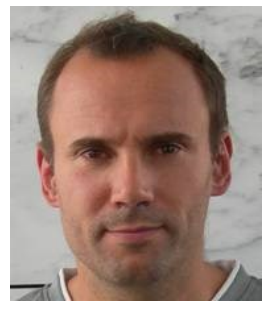

Bruno Douine was born in Montereau, France, in 1966. He received his Ph. D. in electrical engineering from the University of Nancy, France, in 2001.

$\mathrm{He}$ is currently Full Professor at the University of Lorraine and a permanent member of GREEN (Group of Research in Electrical Engineering of Nancy) laboratory. His main topics of research concern characterization of superconducting material and power electronics. 